\title{
Development of Efficiency Management System for Private Kindergarten Schools in Samutprakan Province, Thailand
}

\author{
Praserd Sawaddemongkol, Kanchana Boonphak, Narong Pimsarn \\ King Mongkut's Institute of Technology, Ladkrabang, Thailand \\ Email: 54630153@kmitl.ac.th
}

How to cite this paper: Sawaddemongkol, P., Boonphak, K., \& Pimsarn, N. (2017). Development of Efficiency Management System for Private Kindergarten Schools in Samutprakan Province, Thailand. Creative Education, 8, 1099-1110.

https://doi.org/10.4236/ce.2017.87079

Received: June 1, 2017

Accepted: June 19, 2017

Published: June 22, 2017

Copyright $\odot 2017$ by authors and Scientific Research Publishing Inc. This work is licensed under the Creative Commons Attribution International License (CC BY 4.0).

http://creativecommons.org/licenses/by/4.0/

\begin{abstract}
The development of young learners to become adults who positively contribute to society is crucial to human prosperity and sustainability. As kindergarten is the educational level where learners begin this development, the importance of efficient kindergarten school management is undeniable. This research studied issues relevant to management of private kindergarten schools in Samutprakan province, Thailand, to determine positive factors supporting management of such schools and to develop an effective management system for them. Data were collected from a sample group consisting of local private kindergarten school administrators and teachers using questionnaires, as well as from a focus group of 8 experts in fields pertinent to early childhood education. Results revealed several factors, most notably knowledge and skills of teachers and the leadership of administrators, that greatly affect efficient management. These factors, along with clear management mission principles and the application of the Deming Cycle, were synthesized into a management system that can be utilized in private kindergarten schools in Samutprakan.
\end{abstract}

\section{Keywords}

Early Childhood Education, Kindergarten, Private School Management

\section{Introduction}

Education plays a key role in the development of people, not merely in the passing on of facts and information, but in the multifaceted development of a populace comprised of members who are completely formed emotionally, intellectually, and ethically with the ability to contribute to culture and coexist happily with others and their environment for society at large to be prosperous and sustainable. 
In Thailand, the National Education Act of 1999, amendment 2, section 6, makes the populace's individual physical, mental and social development a direct responsibility of the state. This begins with individuals in the initial stage of formal education, kindergarten, with children aged 1 to 3 years old. At these ages, development of brain cells increases rapidly (Board of Education, 1999). Early childhood education is tasked with making young children ready to learn in a school setting, taking advantage of their natural inclination at this stage to learn quickly in order to adapt them to newfound conditions. Therefore, this initial step of education is critically important in the development of an individual, as it is the foundation upon which further learning and personal growth are built (Sumit \& Niyomka, 2012). Children's future development is greatly impacted by the schooling they receive in these early years, which gives them the tools they will need later in life (Nurmilaakso, 2009). Also of vital importance are the values encountered and taught in this early stage of development as children are bombarded, from birth, by the values of those immediate to them. Day to day, students witness and absorb the values they see demonstrated by their teachers, whether by design or not, and the school environment reaffirms the roles these values play in the culture. To instill and nurture values needed for social interaction and societal sustainability, parents, teachers and educational institutions must work in tandem (Ülavere \& Veisson, 2015). These values shape children into the citizens they will become, and early education must tend to the development of the whole individual to include not just one's intellectual but also physical component. At this stage, learning is to be balanced with caring, each with equal importance, to let children know their place in society, their rights and their responsibilities (Hägglund \& Samuelsson, 2009).

Recognition of the importance of early childhood education by the Thai government is clearly reflected in the National Education Act of 1999, which delineated policy regarding the separation of levels for pre-primary education and the types of institutions catering to children at this level, such as public, community, private, and religious institutions, with the understanding that investment in young children will yield eventual returns in the quality of the country's human capital. This investment comes in the form of assistance in matters of early childhood education, health and nutrition (The Office of the Education Council, 2005).

However, despite Thailand having a large amount of both public and private institutions across the country, there is an insufficient amount of nursery and kindergarten schools for the increasing number of people in densely populated areas, such as big cities. One such area is the province of Samutprakan. Located adjacent to the capital city of Bangkok and home to Thailand's primary international airport, Samutprakan is a growing, bustling province with a large number of industrial facilities, mostly factories, which account for the backbone of its economy, with a 47.9 percent share. Following this is real estate at 14.31 percent. The province has a total of 143 schools, only 36 of which are specifically dedicated to the kindergarten level (Samutprakan Provincial Office, 2014) so private 
institutions share a significant amount of responsibility to meet demand.

The development of young children in Thailand is impacted by many other factors beyond simple coverage and accessibility in regard to the quantity of institutions and availability of space. These involve the readiness of teachers and parents, as well as that of students themselves. Students are not ready to learn and oftentimes parents, usually due to work commitments, have little time to tend to their children. On the school side, many teachers in private kindergartens lack degrees and training specific to early childhood education while administrators with the necessary knowledge and skills for managing at the kindergarten level are few and far between (The Office of the National Education Council, 2007).

It is crucially important that these problems facing kindergarten education be addressed. Adequately preparing children to be ready to learn will positively affect how they develop for the rest of their lives, shaping their awareness and beliefs in terms of who they are and what their place is in their immediate community and larger society (Guseva, Dombrovskis, \& Iliško, 2007). With the human brain's billions of cells in a rapid state of formation at a naturally more rapid pace before the age of six, the early childhood years are critical to individuals further developing fully and appropriately in order to become adults beneficial to the development and sustainability of society as a whole (Preuksawan, 2001).

There is a need to develop systems for the improvement of Thai kindergarten schools in general, starting particularly with the management necessary for such institutions to operate appropriately, efficiently and sustainably within a social context. These institutions must also meet the early developmental requirements essential to the proper intellectual, emotional and physical growth of the individual members of society (Kukasemgrit, 2012).

\section{Objectives}

Given the conditions and problems facing early childhood development, the research aimed to study the operations within kindergarten schools, specifically in private kindergarten schools in Samutprakan province, Thailand, and to determine the factors that contribute to the positive management of such schools in order to utilize the research results for the development of an efficient management system for private kindergarten schools in Samutprakan province.

\section{Conceptual Framework}

For the management of private kindergarten schools, the study focused on the research of kindergarten management principles of Decker and Decker (2005), which discussed the management of early childhood education in the areas of: 1) choice of curricula, 2) recruitment of teachers 3) experience of learning, 4) use of teaching materials, 5) evaluation of student learning and development, 6) facilities, and 7) safety and nutrition.

For the study of positive factors that support the positive management of private kindergarten schools in Samutprakan, the study uses concepts from the re- 
search of Smith and Turkey (cited in Hoy \& Miskel, 1987), which posit that the factors which help promote effective school management can be summarized as follows: 1) knowledge and skills of teachers, 2) leadership of administrators, 3) management system of the school, 4) information systems management, 5), involvement of parents, 6) readiness of facilities, 7) work atmosphere, 8) location of the school, and 9) availability of budget.

The principles and concepts of the study can be summarized as a concept as such (Figure 1).

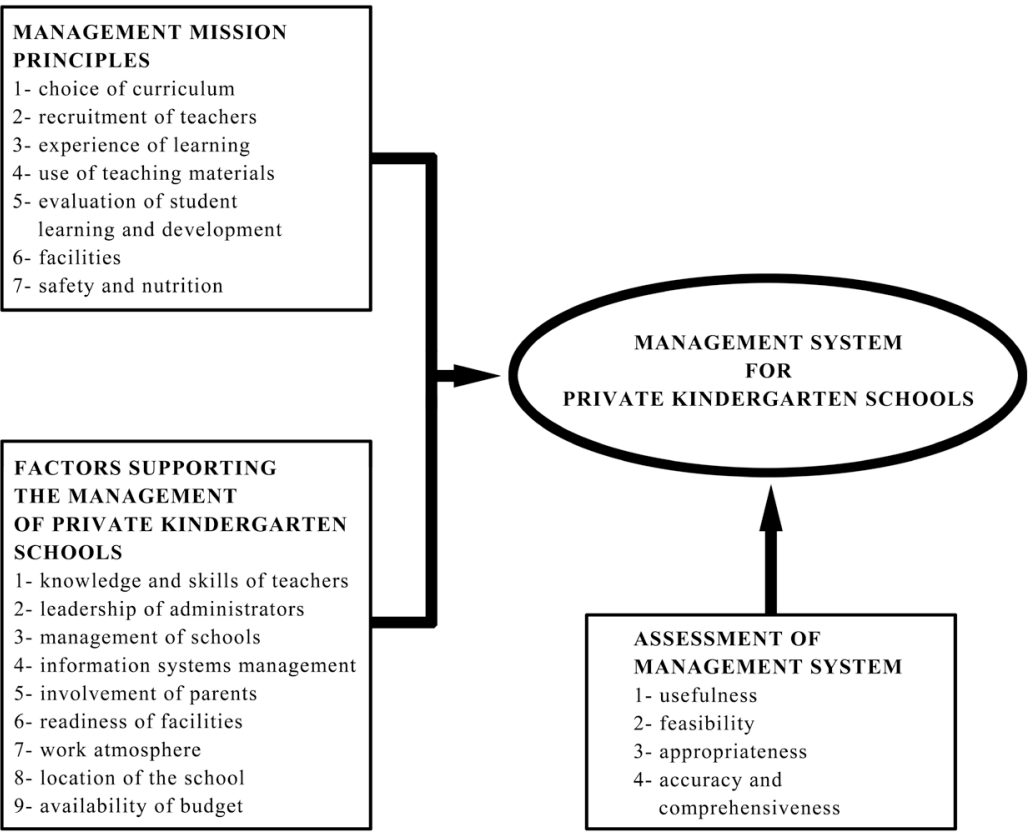

Figure 1. The conceptual framework of the research.

\section{Scope and Methodology}

Samutprakan province has a population of 36 kindergarten schools, with 36 school administrators, and 1,090 teachers, totaling 1126 people.

The sample group consisted of 11 administrators and 274 teachers from private kindergarten schools in Samutprakan, totaling 285 people. The sample size was determined using the Krejcie and Morgan tables and simple random sampling. Data was collected by means of questionnaires with 89.7 percent accuracy and statistical data were calculated through mean standard deviation and stepwise multiple regression analysis

To assess the management of private kindergarten schools in Samutprakan, a discussion group (Focus Group) of 8 experts in fields pertinent to early childhood education was conducted on September 8, 2016 at Bangpleepattanasuksalai School, a private kindergarten, primary and secondary school in Samutprakan.

\section{Summary of Statistical Data}

Of the sample population, the 11 private kindergarten school administrators account for 4 percent of the respondents and the 274 private kindergarten school 
teachers account for 96 percent of the respondents. Respondents with over 6 years of work experience account for 41.82 percent of the sample group, with those at bachelor's degree level 72 percent, at master's degree level 27.27 percent, and doctorate level 0.73 percent, respectively.

The mean standard deviation results, illustrated in Table 1 , indicate that management of private kindergarten schools in Samutprakan is generally at a high level overall for all seven areas, being best in four areas. Curriculum selection and teacher recruitment ranked highest, closely followed by student learning evaluation and learning experience. At the bottom, while still being at relatively high levels, are the areas of learning material usage, safety and nutrition, and facility readiness, which ranked lowest.

The tolerances in Table 2, being lower than 0.10, indicate the correlation of variables and cause multicollinearity. If the tolerance values were greater than 0 , no multicollinearity would occur, and values greater than or equal to 10 would be problematic for the regression model. The Variance Inflation Factor (VIF) values, according to the analysis, are below 10 and cause no problems with multicollinearity and meet the tolerance and VIF criteria as determined by the stepwise multiple regression analysis.

Table 1. The mean standard deviation of management areas for private kindergarten schools in Samutprakan.

\begin{tabular}{|c|c|c|c|c|}
\hline \multirow{2}{*}{ Area of School Management } & \multicolumn{2}{|c|}{$\mathrm{n}=275$} & \multirow{2}{*}{ Level } & \multirow{2}{*}{ Order } \\
\hline & $\bar{x}$ & $\mathrm{~S}$ & & \\
\hline 1. choice of curriculum & 4.55 & 0.46 & highest & 1 \\
\hline 2. recruitment of teachers & 4.55 & 0.46 & highest & 1 \\
\hline 3. experience of learning & 4.53 & 0.44 & highest & 4 \\
\hline 4. use of learning materials & 4.38 & 0.54 & high & 5 \\
\hline 5. evaluation of student learning & 4.55 & 0.44 & highest & 1 \\
\hline 6. readiness of facilities & 4.27 & 0.59 & high & 7 \\
\hline 7. safety and nutrition & 4.28 & 0.59 & high & 6 \\
\hline total & 4.44 & 0.44 & high & - \\
\hline
\end{tabular}

Table 2. VIF (Variance Inflation Factor) of the factors that support the management of private kindergarten schools in Samutprakan.

\begin{tabular}{ccc}
\hline Variable & \multicolumn{2}{c}{ Collinearity Statistics } \\
\cline { 2 - 3 } & Tolerance & VIF \\
\hline knowledge and skills of teachers $\left(\mathrm{x}_{1}\right)$ & 0.109 & 9.143 \\
leadership of administrators $\left(\mathrm{x}_{2}\right)$ & 0.386 & 2.589 \\
school management $\left(\mathrm{x}_{3}\right)$ & 0.338 & 2.960 \\
information systems management $\left(\mathrm{x}_{4}\right)$ & 0.389 & 2.572 \\
parent participation $\left(\mathrm{x}_{5}\right)$ & 0.279 & 3.586 \\
readiness of facilities $\left(\mathrm{x}_{6}\right)$ & 0.308 & 3.244 \\
work atmosphere $\left(\mathrm{x}_{7}\right)$ & 0.324 & 3.088 \\
location of the school $\left(\mathrm{x}_{8}\right)$ & 0.326 & 3.072 \\
\hline
\end{tabular}


In Table 3, of the positive factors for management of private kindergarten schools in Samutprakan, teacher skills $\left(\mathrm{x}_{1}\right)$, school management $\left(\mathrm{x}_{3}\right)$, information systems management $\left(\mathrm{x}_{4}\right)$, parent participation $\left(\mathrm{x}_{5}\right)$, readiness of facilities $\left(\mathrm{x}_{6}\right)$, school location $\left(\mathrm{x}_{8}\right)$ and budget $\left(\mathrm{x}_{9}\right)$ are all determined to be significant, accounted for by the level of statistical significance for these positive changes in private kindergarten school management in Samutprakan.

Error independence as a condition of the regression analysis was tested using Durbin-Watson statistics and equaled a value of 1.971. This value, which is greater than 1.5, indicates independence. The multiple regression coefficients in terms of raw scores (b) equal 0.588, 1.032, 0.832, 0.344, 0.764, -0.607 and 0.235 respectively, with the constant equation of the raw scores (a) being -7.147 , resulting in the following raw score equation:

$$
\begin{aligned}
\hat{Y}= & -7.147+0.588 X_{5}+1.032 X_{1}+0.832 X_{4}+0.344 X_{6} \\
& +0.764 X_{8}-0.607 X_{9}+0.235 X_{3}
\end{aligned}
$$

The standard equation can be generated as follows, considering that the multiple regression coefficients of the variance $(\beta)$ equal $0.361,0.347,0.181,0.391$, $0.150,-0.385$ and 0.179 respectively:

$$
\begin{aligned}
\hat{Z}_{y}= & 0.361 Z_{x_{5}}+0.347 Z_{x_{1}}+0.181 Z_{x_{4}}+0.391 Z_{x_{6}} \\
& +0.150 Z_{x_{8}}-0.385 Z_{x_{9}}+0.179 Z_{x_{3}}
\end{aligned}
$$

\section{Results and Discussion}

To establish an efficient management system for private kindergarten schools in Samutprakan, its primary components can be divided into three distinct parts: 1) the principles that dictate the primary mission of management, 2) the execution of these management mission principles using the integrated quality management principles of the Deming Cycle, and 3) the positive factors identified to be in support of the management of private kindergarten schools in the province of Samutprakan that experts consider to be useful, feasible, appropriate and accurate (Figure 2).

Table 3. Coefficient prediction with standard error of the forecast multiple correlation coefficients (accuracy of prediction using stepwise).

\begin{tabular}{cccccc}
\hline Predictor & $\mathrm{b}$ & $\mathrm{S} . \mathrm{E}_{\mathrm{b}}$ & $\beta$ & $\mathrm{t}$ & $p$-value \\
\hline constant equation in raw score $(\mathrm{a})$ & -7.147 & 0.649 & - & -11.009 & $0.000^{* *}$ \\
parent participation $\left(\mathrm{x}_{5}\right)$ & 0.588 & 0.070 & 0.361 & 8.410 & $0.000^{* *}$ \\
knowledge and skills of teachers $\left(\mathrm{x}_{1}\right)$ & 1.032 & 0.137 & 0.347 & 7.519 & $0.000^{* *}$ \\
information systems management $\left(\mathrm{x}_{4}\right)$ & 0.832 & 0.152 & 0.181 & 5.458 & $0.000^{* *}$ \\
readiness of facilities $\left(\mathrm{x}_{6}\right)$ & 0.344 & 0.055 & 0.391 & 6.241 & $0.000^{* *}$ \\
location of the school $\left(\mathrm{x}_{8}\right)$ & 0.764 & 0.185 & 0.150 & 4.135 & $0.000^{* *}$ \\
availability of budget $\left(\mathrm{x}_{9}\right)$ & -0.607 & 0.117 & -0.385 & -5.183 & $0.000^{* *}$ \\
school management $\left(\mathrm{x}_{3}\right)$ & 0.235 & 0.063 & 0.179 & 3.704 & $0.000^{* *}$
\end{tabular}

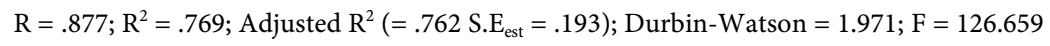

a. ${ }^{* *}$ denotes statistical significance at $\leq 0.01$. 


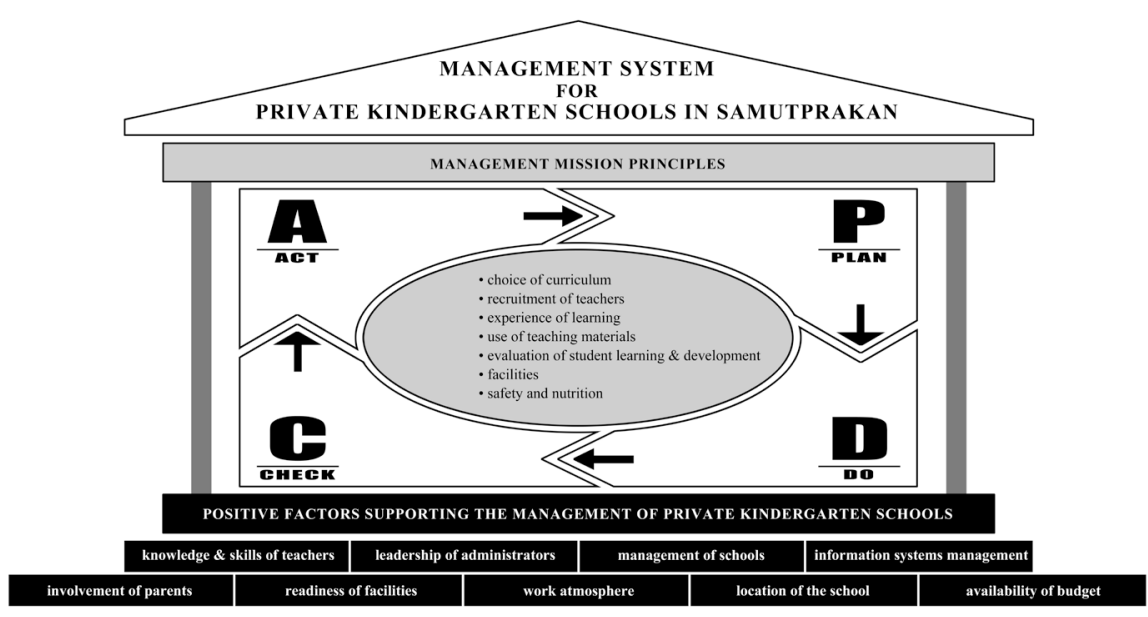

Figure 2. The management system for private kindergarten schools in Samutprakan.

The primary mission of management for private kindergarten schools is comprised of seven main tasks: 1) the choice of curricula, 2) the recruitment of teachers, 3) the experience of learning, 4) the use of teaching materials, 5) the evaluation of student learning and development, 6) facilities, and 7) safety and nutrition. For the organization to reach its goals of being useful, feasible, appropriate and accurate in coverage, management must see to the efficient execution of these tasks. While schools across the country may operate in different ways or have differing names for the aforementioned tasks, kindergarten schools, both public and private, in practice utilize the curriculum of the Early Childhood Education Act of 2013 with schools able to tailor some content as deemed appropriate for local considerations, such as the parental needs, customs, traditions and culture specific to the location of the school. As the most heavily industrialized province in the country, Samutprakan itself is affected by rapid change and is faced with issues different to those of other provinces. The way of life for both those residing in the province and those who commute to work in Samutprakan is in stark contrast with the relatively simple pace of smaller provinces, as the bustle and competitiveness inherent to large cities is ever present. Urbanization negatively impacts sustainable living for young children, particularly in health development and quality of life and thus sustainable education requires tandem consideration of not only curricula and pedagogy but also a child's physical and social environments (Davis, 2010).

One notable issue concerning Samutprakan's physical environment is travel within the province. The daily commute to and from work or school is at the mercy of routinely congested traffic conditions. The toll on the time parents have to spend with and care for their children significantly affects young children's development and their readiness for schooling, and impacts education directly. To help people adapt to these evolving lifestyles, preparations must start at an early age and ease said people into life in this industrial province in a systematic manner. Virtues such as self-discipline, environmental awareness, diligence, patience, punctuality and especially creative thinking are necessary for individuals to strive in an economy such as that of Samutprakan's and must be 
instilled early in children through education for them to function responsibly as citizens and be a positive force for the sustainability of their society. To this end, the quality of early childhood education is vitally important although unfortunately often this stage of education receives less attention than later ones. Preparing young children adequately to interact with and survive in their environment is a necessary preventative measure and less costly than correcting societal problems when they occur later as threats to personal well-being and societal sustainability (Davis, 2009).

Consideration must also be seriously given to foreign language skills, most notably in English, made necessary by the influx of people and businesses into Samutprakan from abroad. These factors and more make it vitally important and necessary that management of kindergarten schools of private kindergarten schools in Samutprakan take action to ensure that the children they service are put on the right path towards succeeding in their immediate environment.

For the execution of these management mission principles, the application of the Deming Cycle of planning, doing, checking and acting or adjusting, popularly abbreviated as PDCA, is commonly used to achieve quality, that is, effective and sustainable, management processes. Experts agree that the Deming Cycle is a productive tool that can help institutions be useful, feasible, appropriate and accurate, and it is a practice already adopted by many private kindergarten schools in Samutprakan. For example, PDCA can be applied to the recruitment of teachers. A common problem facing private kindergarten schools in Samutprakan is the recruitment, training and especially retention of teachers, as teachers are prone to resign from their positions, oftentimes under the space of a year and without adequate prior notification. Schools must have systems in place to "plan" for such eventualities, including policies to ensure proper notification prior to the fact should a teacher decide to resign. An adequate time frame must be determined, perhaps one or two months, as necessary to recruit and train replacement staff which would dictate the length of time necessary for prior notice on the part of the departing teacher. That recruitment and training period is the "doing," wherein new staff is put in place and prepared for the demands of the job. Once the new teacher is in place, their performance is to be evaluated, or "checked," to see if it meets the criteria and standards of the school. From these evaluations, judgments can be made in terms of which areas of performance the new teacher needs to develop, or "act upon or adjust," to meet standards. Recruitment and training of teachers is an essential task for any school, but the Deming Cycle can be applied to all other operations as well.

The factors supporting effective management of private kindergarten schools in Samutprakan province, as identified by experts are as follows, from high to low: 1) the knowledge and skills of teachers, 2) the leadership of administrators, 3 ) the management system of the school, 4) information systems management, 5) the involvement of parents, 6) the readiness of facilities, 7) the work atmosphere, 8) the location of the school, and 9) the availability of budget. Therefore, all the observed factors are significant in predicting the usefulness, feasibility, 
appropriateness and accurate reach of the institution. That the "knowledge and skills of teachers" ranked first reflects the importance of the teacher-student relationship, specifically the role the teacher plays as the person who directly teaches, trains and cares for each student, creating meaningful learning experiences that shape the physical, mental, emotional and social development that prepare children for primary 1, the first mandatory level of education. It is important to note that the skillset for kindergarten teachers is distinctly different from those of teachers in other levels, as there is a specific demand for kindergarten teachers to design and continually implement children's activities since children at this age need additional support (Nurmilaakso, 2009). Kindergarten teachers must possess qualities of compassion, diligence, tolerance, and understanding; all necessary for their interactions with both young children and parents. The factor ranking second, "the leadership of administrators," reflects the undeniable importance of managers in private kindergartens, as they are those who influence success in every dimension of an organization's processes. Management must make leadership decisions regarding myriad considerations including, but not limited to, personnel, daily operations, resources, and finances. Management is also responsible for coordination with parties both within and outside the institution, such as educational authorities, public health agencies, parents, community leaders and other stakeholders. Managerial decisions are key to the overall smooth running of an organization, either positively or negatively affecting morale, work atmosphere and the ability of the kindergarten school as a whole to not just be sustainable but to improve and prosper. While ranking noticeably lower, "the location of the school," is still a notable factor that should not be disregarded given the unique conditions caused by the large quantity of industrial facilities in Samutprakan. The effects of population and vehicular density make location a necessary consideration for parents, especially in relation to private school choice. If a kindergarten school is conveniently located and easily accessed, such as having proximity to home, hospitals or public healthcare facilities, it will become a more attractive option for parents in their decision making.

\section{Conclusion}

The research results indicate that knowledge and skills of teachers, the leadership of administrators, the management of schools, information systems management, the involvement of parents, the readiness of facilities, work atmosphere, the location of the school and the availability of budget are all positive factors supporting the management of private kindergarten schools in Samutprakan. These factors are applicable to all levels of education, but are especially relevant to the educational management of kindergarten schools. From the nine variables above, seven are especially significant. They are: the knowledge and skills of teachers, the management of schools, information systems management, the involvement of parents, the readiness of facilities, the location of the school and the availability of budget. The involvement of parents is of particular note. 
In line with the Private Education Act of 2007, the participation of not only parents, but also the community at large, has a significant impact on early childhood education and development (Ifju \& Balta, 2004). This is consistent with the research of Hankiettipong (2012), which also analyzed the factors that affect excellence in management of private kindergarten schools. Being a sustainable school involves the school as a whole and the community around it, with quality teaching and active learning which engage not just students, but their teachers, families and the community at large to play a role in forging the future direction of their society (Cooke, Davis, Blashki, \& Best, 2010).

The realities of the modern family unit cause parents and children to have less and less time together and teachers of young children need to be prepared to act essentially as surrogate parents. Therefore, the skills of teachers and the involvement of parents are strongly linked to each other. Cooperation and coordination between the educational institution and the family unit is key to the quality of children's learning (Sakk, Veisson, \& Lukk, 2009). Parent education, that is, giving parents proper knowledge and skills to adequately care for their children and work together with schools to instill in them desired virtues and sustainable habits, is also a notable avenue that merits attention and consideration (Zepeda, Varela, \& Morales, 2004).

The remaining two factors, administrative leadership and work atmosphere, while inherent to daily operations, did not register as significantly. Further research may be warranted, however, especially into possible effects on outcomes from demographics. The research also found that there are 4 variables that could explain the variability of managerial excellence in private kindergartens being at 79.28\%. These variables are 1) school factors, 2) teacher and other personnel factors, 3) management factors, and 4) external environmental factors, illustrating the various and interlocking issues at play. These can be seen as consistent factors, and are important considerations in relation to efficient management of private kindergarten schools.

The management system derived from the study and analysis of issues, research, principles and expert commentary relevant to kindergarten school management, with consideration for the specific conditions found in Samutprakan province, allows for clear understanding of the mission of management as well as the factors affecting successful administration in order to manage private kindergarten schools to be useful, feasible, appropriate and accurate in their coverage. The implementation of this management system can be a positive step towards the success and sustainability of private kindergarten schools in Samutprakan.

\section{Acknowledgements}

Special thanks to Prof. Dr. Kanchana Boonphak and Dr. Narong Pimsarn for their invaluable contribution as advisors to this research, consistently providing expert support and guidance throughout the entire research. Thanks also to all the participating individuals and institutions for their part in data collection. Fi- 
nally, the researcher is sincerely grateful to the family members, friends and colleagues whose constant encouragement is much appreciated.

\section{References}

Board of Education (1999). National Education Act of 1999. Bangkok: Prikwan Graphics Ltd.

Cooke, S. M., Davis, J. M., Blashki, G. A., \& Best, A. F. (2010). Healthy Children, Healthy Planet: The Case for Transformative Sustainability Education in Schools and Early Childhood from an Australian Perspective. International Public Health Journal, 2, 561-570.

Davis, J. (2009). Revealing the Research "Hole" of Early Childhood Education for Sustainability: A Preliminary Survey of the Literature. Environmental Education Research, 15, 227-241. https://doi.org/10.1080/13504620802710607

Davis, J. (2010). Early Childhood Education for Sustainability: Why It Matters, What It Is, and How Whole Centre Action Research and Systems Thinking Can Help. Journal of Action Research Today in Early Childhood, 35-44.

Decker, C. A., \& Decker, J. R. (2005). Planning and Administering Early Childhood Programs. Upper Saddle River, NJ: Prentice Hall.

Guseva, S., Dombrovskis, V., \& Iliško, D. (2007). Preparing Children for School: The Perspective of Sustainability. Journal of Teacher Education for Sustainability, 8, 48-58. https://doi.org/10.2478/v10099-009-0012-7

Hägglund, S., \& Samuelsson, I. P. (2009). Early Childhood Education and Learning for Sustainable Development and Citizenship. International Journal of Early Childhood, 41, 49. https://doi.org/10.1007/BF03168878

Hankiettipong, S. (2012). Analysis of Factors Affecting the Management of Private Kindergartens. Thesis, Bangkok: Chulalongkorn University.

Hoy, W. K., \& Miskel, G. G. (1987). Educational Administration: Theory, Research, and Practice. New York: Random House Trade.

Ifju, T., \& Balta, C. L. (2004). Parents' and Local Community's Involvement in Early-Age Education Programs in Kindergarten. Educa IA-Plus Journal plus Education, 5, 235243.

Kukasemgrit, D. (2012). Early Great Discipline: Never Obsolete. Press Journal of Research and Development (Field of Human and Social Sciences), 4.

Nurmilaakso, M. (2009). Preschool and Primary School Children as Learners in 2030: Views of Finnish Student Teachers. Journal of Teacher Education for Sustainability, 11, 75-85. https://doi.org/10.2478/v10099-009-0034-1

Preuksawan, B. (2001). New Dimension in Teaching Reading. Bangkok: Thaiwattanapanich.

Sakk, M., Veisson, M., \& Lukk, K. (2009). The Quality of Family Relations in Ensuring Sustainable Education. Journal of Teacher Education for Sustainability, 11, 51-63. https://doi.org/10.2478/v10099-009-0040-3

Samutprakan Provincial Office (2014). Development Plan for Samutprakan Province for 2015 to 2021. Samutprakan Planning Department.

Sumit, T., \& Niyomka, P. (2012). Waiting until Kindergarten Was Too Late Already. Bangkok: Samut Sakhon.

The Office of the Education Council (2005). A Study of the Statistics from the 2013-2014 Academic Year. Bangkok: Prikwan Graphics Ltd. 
The Office of the National Education Council. (2007). Policy and Strategy Development: Early Childhood (0 - 5 Years) for the Term of 2007-2016. Bangkok: VTC Communications.

Ülavere, P., \& Veisson, M. (2015). Values and Values Education in Estonian Preschool Childcare Institutions. Journal of Teacher Education for Sustainability, 17, 108-124. https://doi.org/10.1515/jtes-2015-0014

Zepeda, M., Varela, F., \& Morales, A. (2004). Promoting Positive Parenting Practices through Parenting Education. Building State Early Childhood Comprehensive Systems Series, Number 13. UCLA Center for Healthier Children, Families and Communities.

Submit or recommend next manuscript to SCIRP and we will provide best service for you:

Accepting pre-submission inquiries through Email, Facebook, LinkedIn, Twitter, etc. A wide selection of journals (inclusive of 9 subjects, more than 200 journals) Providing 24-hour high-quality service

User-friendly online submission system Fair and swift peer-review system Efficient typesetting and proofreading procedure Display of the result of downloads and visits, as well as the number of cited articles Maximum dissemination of your research work

Submit your manuscript at: http://papersubmission.scirp.org/ Or contact ce@scirp.org 